DOI: 10.17707/AgricultForest.64.3.06

Veselinka ZEČEVIĆ, Jelena BOŠKOVIĆ, Slobodan MILENKOVIĆ, Mirela MATKOVIĆ STOJŠIN, Jasmina BALIJAGIĆ, Nevena ĐUKIĆ, Desimir KNEŽEVIĆ ${ }^{1}$

\title{
PHENOTYPIC VARIABILITY OF YIELD COMPONENTS OF Triticum spelta IN ORGANIC PRODUCTION
}

\begin{abstract}
SUMMARY
The aim of this study was to investigate phenotypic variability of yield components for different spelt wheat genotypes (Triticum spelta L.). Six genotypes of winter spelt wheat (Nirvana, KG-37-8/3, KG -54-7/3, KG -54-8/1, KG -54-4/2, and KG-54-2/3) were grown during two growing seasons (2011/2012 and 2012/2013) at certified organic trial parcel in the Municipality of Čačak, Serbia. Through variance analysis, highly significant differences in mean values for both investigated yield components (number of grains per spike and grain weight per spike) were established. Higher values of coefficient of variability for grain weight per spike $(C V=12.8 \%)$ than grain number per spike $(C V=10.2 \%)$ were determined. The highest average value for number of grains per spike had genotype KG-54-7/3 (46.22). Genotype KG-54-2/3 (1.94 g) had significantly higher mass of hulled grains per spike compared to other investigated genotypes. Phenotypic analysis of variance indicated that ecological factors had higher impact on the expression of grain weight per spike, but genetic factors had higher impact on the expression of number of grains per spike. variance.

Keywords: Wheat, spelt, variability, yield components, phenotypic
\end{abstract}

\section{INTRODUCTION}

Spelt (Triticum spelta L.) is an old wheat species whose production greatly decreased in the 20th century but the interest for this low-input wheat has recently increased again, and spelt is recognized as one of the most appropriate cereals for organic production (Bavec and Bavec, 2011). The growing of spelt wheat has recently become very popular, particularly with regard to use in special bakery products, health and organic foods. Growing this cereal is also becoming more interesting in Serbia. Areas under spelt wheat are increasing in hilly mountains and lowland regions as well (Glamočlija et al., 2013).

\footnotetext{
${ }^{1}$ Veselinka Zečević (corresponding author: joca@kg.ac.rs), Slobodan Milenković, Mirela Matković Stojšin, Megatrend University Belgrade, Faculty of Biofarming, Bačka Topola, SERBIA; Jelena Bošković, University Business Academy in Novi Sad, Faculty of Economics and Engineering Management, SERBIA; Jasmina Balijagić, University of Montenegro, Biotechnical Faculty, Podgorica, MONTENEGRO; Nevena Đukić, University of Kragujevac, Faculty of Science, Kragujevac, SERBIA; Desimir Knežević, University of Priština, Faculty of Agriculture, Lešak, SERBIA

Notes: The authors declare that they have no conflicts of interest. Authorship Form signed online.
} 
Spelt's popularity has seen a more recent resurgence largely due to its health benefits and its distinctive taste attributes. Spelt is very highly regarded as an alternative grain due to its great nutritional value. This species is very high in protein (Kohajdova and Karičova, 2008, Moudrý et al., 2011, Siemianowska et al., 2011) and various minerals and vitamins (Piergiovanni et al., 1997, Bojňanská and Frančaková, 2002), higher in selenium content (Zhao et al., 2009), abundant in soluble fibers (Bonifacia et al., 2000) and has more favorable ratio of unsaturated to saturated fatty acids (Ruibal-Mendieta et al., 2004), while containing a low amount of fat and a moderate amount of gluten. The grain's gluten content makes it suitable for some baking. Today, more spelt-based products are available including flour, bread, crackers (Konvalina et al., 2013, Filipčev et al., 2013), and pasta (Marques et al., 2007). There are many applications of spelt in bakery industry but not in the beverage industry, which makes new approaches in the malting and brewing process for further investigation. Study of Muñoz-Insa et al. (2013) shows a new possibility to adopt the production of spelt beverages and further expands the market of alternative cereals.

Spelt is adapted to lower fertility soils and shows higher resistance to environmental influences than common wheat, giving it greater suitability for organic farming. Under optimal growing conditions, the yields of organically grown spelt are lower than organically grown wheat. Under sub-optimal growing conditions some research suggests that spelt out-performs many traditional grains (such as wheat) and is able to better utilize nutrients when grown in a low-input system, suggesting that spelt could play a greater role in organic cereal rotations (Neeson, 2011). Experience shows that yield potential in organic farming varies much more widely than in conventional agriculture. Therefore expectations for organic varieties include higher adaptability and plasticity, combined with consistently high quality.

Organic plant breeding is a new direction in plant breeding aimed at creating so called organic agricultural plant varieties that are adapted to the conditions and requirements of organic production. New varieties for organic production must have a greater resistance to abiotic and biotic stress conditions, more efficient uptake of mineral nutrients and better exploit of the existing environmental conditions. Since the problems of weeds in organic crop production are more pronounced if it's the initial criteria, it is certain that varieties incurred by this means should be selected, based on the other grounds (Berenji, 2009). One of the basic mechanisms of weed control in organic production is the competitiveness of organic species and weeds that expressed the power suppressing weeds by organic varieties. Resistance / tolerance to pests and diseases are among the most important expectations of the organic varieties (Berenji and Sikora, 2009). Organic plant breeding aims to respect natural species authenticity. Crosses between species should not be forced if fertilization and embryo growth do not succeed on the plant. Also, organic plant breeding aims to achieve a species-specific equilibrium for an optimal development of 
species-specific characteristics, such a taste, color, bouquet and shape (Lammerst van Bueren et al., 1999).

The aim of this paper was to study phenotypic variability for yield components in spelt genotypes which can be used as parent cultivars in organic plant breeding programs for improvement of grain yield and quality of spelt wheat.

\section{MATERIAL AND METHODS}

Six genotypes of winter spelt wheat (Nirvana, KG-37-8/3, KG -54-7/3, KG -54-8/1, KG -54-4/2, and KG-54-2/3) were grown during two growing seasons (2011/2012 and 2012/2013) at certified organic trial parcel which is

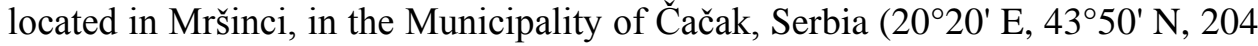
$\mathrm{m}$ asl). The yearly mean air temperature of the area is $11.6^{\circ} \mathrm{C}$; and the average annual rainfall in the area is around $669 \mathrm{~mm}$. Average temperature and precipitation for vegetative period (October-June) in the 2011/2012 were $8.7{ }^{\circ} \mathrm{C}$ and $345.5 \mathrm{~mm}$, respectively. In the $2012 / 2013$ average temperature and precipitation were higher $\left(10.1^{\circ} \mathrm{C}\right.$ and $503.0 \mathrm{~mm}$, respectively).

Cultivar Nirvana is the property of the Institute of Field and Vegetable Crops, Novi Sad, and other investigated genotypes are the property of the Small Grains Research Centre Kragujevac.

The field experiment was conducted in a randomized block design with three replications with plot of $5 \mathrm{~m}^{2}$ on the soil which belongs to the loamy clay type. The sowing density was 600 seeds per square meter. Experiment was carried out by the organic technology of scientific farming production of wheat. Soybean in the first and potato in the second year were used as the preceding crops. Sowing was carried out in the first decade of November. The treatment of the crops during the growing season respected the principles of the organic farming.

For analysis of spike characteristics 60 plants in full maturity stage (20 plants per replication) were used. The primary spike was used for analysis of yield components. The number of grains per spike and dehulled grain mass per spike were determined.

The following parameters were computed: the average value $(\bar{x})$, the standard deviation (SD), the coefficient of variation (CV), and analysis of variance (ANOVA). The significant differences between the average values were estimated by LSD-test. The ANOVA was performed according to a random block system with two factors using the MSTAT-C program (Michigan State University, 1990). Components of variance $\left(\sigma^{2}{ }_{\mathrm{g}}\right.$-genetic, $\sigma_{\text {gl }}^{2}$-interaction; $\sigma_{\mathrm{E}^{-}}^{2}$ environment; $\sigma_{\mathrm{f}}^{2}$-phenotypic) were calculated according to the Falconer (1981).

\section{RESULTS AND DISCUSSION}

Grain number per spike is an important yield component, which directly affects genetic yield potential. The results for number of grains per spike are presented in Table 1. According to the results, number of grains per spike 
depended significantly on genotype and genotype $\times$ year interaction. Variability between varieties was higher than between investigated growing seasons. In this research, average value for this trait is varied in the range of 34.01 to 46.22 grains per spike. The highest average value for number of grains per spike was observed in genotype KG-54-7/3 (46.22), and the lowest in Nirvana variety (34.01). Variability of this yield component differed between growing seasons. Higher variability was established in the first $(\mathrm{CV}=11.82 \%)$ than in the second year $(\mathrm{CV}=8.68 \%)$.

The coefficient of variation varied in the range from 5.3\% (Nirvana in the second year) to $19.5 \%$ (KG-37-8/3 in the first year). Cultivar Nirvana had about 34 grains per spike on average, which concurred with previous investigations. According to Pospisil et al. (2011), cultivar Nirvana produced from 32.9 to 40.0 grains per spike in dependence to crop management and growing season. The number of grains per spike is a quantitative trait whose expression depends on a large number of genes that are strongly influenced by environmental factors that cause high variability, as confirmed by this research.

Table 1. Average values and variability for number of grains per spike

\begin{tabular}{|c|c|c|c|c|c|c|c|}
\hline \multirow[b]{3}{*}{ Genotype } & \multicolumn{6}{|c|}{ Year } & \multirow[b]{3}{*}{ Average } \\
\hline & \multicolumn{3}{|c|}{ 2011/2012 } & \multicolumn{3}{|c|}{ 2012/2013 } & \\
\hline & $\bar{x}$ & SD & $C V(\%)$ & $\bar{x}$ & SD & $\begin{array}{l}C V \\
(\%)\end{array}$ & \\
\hline Nirvana & $36.55 \pm 0.51^{\mathrm{d}}$ & 3.94 & 10.8 & $31.47 \pm 0.22^{\mathrm{e}}$ & 1.67 & 5.3 & $34.01 \pm 0.36^{\mathrm{C}}$ \\
\hline KG-37-8/3 & $37.26 \pm 0.94^{\text {cd }}$ & 7.28 & 19.5 & $40.63 \pm 0.85^{\mathrm{bc}}$ & 6.60 & 16.2 & $38.94 \pm 0.89^{\mathrm{B}}$ \\
\hline KG-54-7/3 & $45.44 \pm 0.66^{\mathrm{a}}$ & 5.08 & 11.2 & $46.99 \pm 0.46^{\mathrm{a}}$ & 3.53 & 7.5 & $46.22 \pm 0.56^{\mathrm{A}}$ \\
\hline KG-54-8/1 & $39.51 \pm 0.62^{\text {bcd }}$ & 4.78 & 12.1 & $40.90 \pm 0.54^{\mathrm{bc}}$ & 4.18 & 10.2 & $40.21 \pm 0.58^{\mathrm{B}}$ \\
\hline KG-54-4/2 & $40.05 \pm 0.52^{\mathrm{bcd}}$ & 4.02 & 10.0 & $41.60 \pm 0.40^{\mathrm{b}}$ & 3.11 & 7.4 & $40.83 \pm 0.46^{\mathrm{B}}$ \\
\hline KG-54-2/3 & $45.41 \pm 0.43^{\mathrm{a}}$ & 3.32 & 7.3 & $46.67 \pm 0.33^{\mathrm{a}}$ & 2.56 & 5.5 & $46.04 \pm 0.38^{\mathrm{A}}$ \\
\hline Average & $40.70 \pm 0.61$ & 4.74 & 11.82 & $41.38 \pm 0.47$ & 3.61 & 8.68 & $41.04 \pm 0.54$ \\
\hline
\end{tabular}

Mean values of genotypes in both years denoted with different small letters are significantly different according to LSD test $(\mathrm{P} \leq 0.05)$; Mean values of genotypes for both years denoted with different capital letters are significantly different according to LSD test $(\mathrm{P} \leq 0.05)$.

Analysis of variance for the number of grains per spike is shown in Table 2. The analysis of phenotypic variance established highly significant $F$ values for varieties and significant for interaction varieties $\times$ year. Most of the total phenotypic variance belongs to genotype (73.48\%), less to interaction (12.30\%), and the least belonged to environmental factors (1.87\%).

Average values and variability of the hulled grain weight per spike are shown in Table 3 . The grain weight per spike is very variable trait because it depends on grain number and grain chemical composition. This trait is very important yield component, which directly influences harvest index and yield. 
This yield component is very variable and its expression depends highly on the environmental factors. Examined varieties reacted differently to environmental changes during particular years. Average grain weight per spike in all analyzed varieties was $1.66 \mathrm{~g}$, ranging from $1.525 \mathrm{~g}$ (KG-54-8/1) to $1.940 \mathrm{~g}$ (KG-54-2/3). Genotype KG-54-2/3 produced significantly higher mass of hulled grains compared to other investigated genotypes.

Table 2. Results of ANOVA and variance components for number of grains per spike

\begin{tabular}{|l|c|c|c|c|c|c|c|}
\hline \multirow{2}{*}{ Source } & \multirow{2}{*}{$\begin{array}{c}\text { Mean } \\
\text { square }\end{array}$} & $F$ & \multirow{2}{*}{$\begin{array}{c}\text { Components of } \\
\text { variance }\end{array}$} & \multicolumn{2}{|c|}{ LSD } \\
\cline { 5 - 9 } & & & & $s^{2}$ & $\%$ & 0.05 & 0.01 \\
\hline Replication & 2 & 0.578 & 0.1798 & - & - & - & - \\
\hline Genotype & 5 & 127.680 & $39.6773^{* *}$ & 19.142 & 73.48 & 2.662 & 4.176 \\
\hline Year & 1 & 4.101 & $1.2743^{\text {ns }}$ & 0.485 & 1.87 & 1.240 & 1.686 \\
\hline $\begin{array}{l}\text { Genotype } \\
\text { year }\end{array}$ & 5 & 12.831 & $3.9873^{*}$ & 3.204 & 12.30 & 3.765 & 5.906 \\
\hline Error & 22 & 3.218 & & 3.218 & 12.35 & - & - \\
\hline Total & 35 & - & - & 26.049 & 100.00 & - & - \\
\hline
\end{tabular}

${ }^{\text {ns }} P>0.05 ; * P \leq 0.05 ; * * P \leq 0.01$

High variability and significant differences for grain weight per spike in different varieties were established by analysis of variance (Table 4). Phenotypic variance analysis showed highly significant differences for grain weight per spike between cultivars, experimental years and their interactions, which agree with previous studies (Jablonskytė-Raščè et al., 2013).

The highest percentage of the total phenotypic variability was assigned to year $(50.00 \%)$, less to genotype $(29.73 \%)$, and only $14.86 \%$ to interaction genotype $\times$ year. This suggests that environmental factors in this study played a major role in the expression of grain weight per spike, what agree with previous results (Zečević et al., 2010). In previous studies (Lacko-Bartošová et al., 2010), weight of grains per spike was also statistically significantly dependent on variety and weather conditions.

Spike properties of wheat depended highly on the genotypes, environmental conditions (Zečević et al., 2013), soil quality (Glamočlija et al., 2013), and applied cultivation technology (Bicanova et al. 2008). Bavec et al. (2011) also established significant influence of the production year and production system on yields for spelt and common wheat. They pointed out that differences among production systems in spelt are not as accentuated as in the case of common wheat, possibly due to the lower breeding modifications of spelt as compared to wheat and the somewhat unresponsive reaction to additional nitrogen fertilizer applications. 
Table 3. Average values and variability of grain weight per spike

\begin{tabular}{|c|c|c|c|c|c|c|c|}
\hline \multirow[b]{3}{*}{ Genotype } & \multicolumn{6}{|c|}{ Year } & \multirow[b]{3}{*}{ Average } \\
\hline & \multicolumn{3}{|c|}{ 2011/2012 } & \multicolumn{3}{|c|}{ 2012/2013 } & \\
\hline & $\bar{x}_{(\mathrm{g})}$ & SD & $C V(\%)$ & $\bar{x}_{(\mathrm{g})}$ & SD & $\begin{array}{l}C V \\
(\%)\end{array}$ & \\
\hline Nirvana & $1.497 \pm 0.02^{\mathrm{d}}$ & 0.17 & 11.4 & $1.633 \pm 0.13^{\mathrm{bc}}$ & 0.10 & 6.1 & $1.565 \pm 0.08^{\mathrm{C}}$ \\
\hline KG-37-8/3 & $1.493 \pm 0.03^{\mathrm{d}}$ & 0.25 & 16.7 & $1.713 \pm 0.04^{\mathrm{bc}}$ & 0.29 & 16.9 & $1.603 \pm 0.04^{\mathrm{C}}$ \\
\hline KG-54-7/3 & $1.607 \pm 0.02^{\mathrm{cd}}$ & 0.16 & 10.0 & $1.987 \pm 0.04^{\mathrm{a}}$ & 0.28 & 14.1 & $1.797 \pm 0.03^{\mathrm{B}}$ \\
\hline KG-54-8/1 & $1.317 \pm 0.02^{\mathrm{e}}$ & 0.14 & 10.6 & $1.733 \pm 0.04^{\mathrm{bc}}$ & 0.34 & 19.6 & $1.525 \pm 0.03^{\mathrm{C}}$ \\
\hline KG-54-4/2 & $1.313 \pm 0.03^{\mathrm{e}}$ & 0.20 & 15.2 & $1.763 \pm 0.02^{\mathrm{b}}$ & 0.20 & 11.3 & $1.538 \pm 0.02^{\mathrm{C}}$ \\
\hline KG-54-2/3 & $1.907 \pm 0.02^{\mathrm{ab}}$ & 0.16 & 8.4 & $1.973 \pm 0.04^{\mathrm{a}}$ & 0.28 & 14.2 & $1.940 \pm 0.03^{\mathrm{A}}$ \\
\hline Average & $1.52 \pm 0.02$ & 0.18 & 12.0 & $1.80 \pm 0.05$ & 0.38 & 13.7 & $1.66 \pm 0.04$ \\
\hline
\end{tabular}

Mean values of genotypes in both years denoted with different small letters are significantly different according to LSD test ( $\mathrm{P} \leq 0.05)$; Mean values of genotypes for both years denoted with different capital letters are significantly different according to LSD test $(\mathrm{P} \leq 0.05)$.

Table 4. Results of ANOVA and variance components for grain weight per spike

\begin{tabular}{|l|c|c|c|c|c|c|c|}
\hline \multirow{2}{*}{ Source } & \multirow{2}{*}{$\begin{array}{c}\text { Mean } \\
\text { square }\end{array}$} & \multirow{2}{*}{$F$} & \multicolumn{2}{|c|}{$\begin{array}{c}\text { Components of } \\
\text { variance }\end{array}$} & \multicolumn{2}{|c|}{$L S D$} \\
\cline { 5 - 9 } & & & & $s^{2}$ & $\%$ & 0.05 & 0.01 \\
\hline Replication & 2 & 0.000 & 0.0407 & - & - & - & - \\
\hline Genotype & 5 & 0.171 & $48.1048^{* *}$ & 0.022 & 29.73 & 0.0984 & 0.1472 \\
\hline Year & 1 & 0.697 & $196.3736^{* *}$ & 0.037 & 50.00 & 0.0435 & 0.0591 \\
\hline Genotype $\times$ year & 5 & 0.038 & $10.7492^{* *}$ & 0.011 & 14.86 & 0.1327 & 0.2082 \\
\hline Error & 22 & 0.004 & - & 0.004 & 5.41 & - & - \\
\hline Total & 35 & - & - & 0.074 & 100.00 & - & - \\
\hline
\end{tabular}

$* * P \leq 0.01$

For organic farming, varieties with high tillering capacity where yield is based on number of ears should not be chosen. These varieties need sufficiency of nutrients at the beginning of spring vegetation. However, there is lack of nutrients in soil because of low microbial activity and low level of mineralization (Bicanova et al., 2008).

\section{CONCLUSIONS}

These investigations indicated that ecological factors had high impact on the expression of grain weight per spike and number of grains per spike of spelt wheat in organic production. Through variance analysis, highly significant differences in mean values for both investigated yield components were established. High variability for both investigated yield components was determined. The highest average value for number of grains per spike had genotype KG-54-7/3, while genotype KG-54-2/3 produced significantly higher mass of hulled grains compared to other investigated genotypes. These genotypes can be used in breeding programs for increasing yield in spelt wheat. 


\section{ACKNOWLEDGEMENTS}

This work was supported by the Ministry of Education, Science and Technological Development of the Republic of Serbia within the Project of technological development No. TR 31092.

\section{REFERENCES}

Bavec M., Narodoslawsky M., Bavec F., Turinek M. 2011. Ecological impact of wheat and spelt production under industrial and alternative farming systems. Renewable Agriculture and Food Systems, 27: 242-250.

Berenji J. 2009. The role of cultivar and certified seed in organic agriculture. Proceedings of Institute of Field and Vegetable Crops, Novi Sad. 46 (1): 11-16.

Berenji J., Sikora V. 2009. Organic breeding - a new direction in plant breeding. Plant Breeding and Seed Production, 15, 13-22.

Bicanová E., Dvořák P., Capouchová I. 2008. Effect of growth structure, variety and year on yield of organic wheat. In: Proceedings (Eds: M. Pospisil). 43rd Croatian and 3rd International Symposium on Agriculture, Opatija, Croatia, 18-21 February, 2008. Faculty of Agriculture, University of Zagreb, pp. 140-143.

Bojňanská T., Frančáková H. 2002. The use of spelt wheat (Triticum spelta L.) for baking applications. Rostlinná Výroba, 48: 141-147.

Bonifácia G., Galli V., Francisci R., Mair V., Skrabanja V., Kreft I. 2000. Characteristics of spelt wheat products and nutritional value of spelt wheat-based bread. Food Chemistry, 68: 437-441.

Glamočlija Dj., Janković S., Popović V., Ugrenović V., Zekić N., Ikanović J., Rakić S. 2013. Morphological and production characteristics of spelt wheat on chernozem and degraded soil. Proceedings of IV International Scientific Symposium "Agrosym Jahorina 2013", Serbia, pp. 364-369.

Falconer D.S. 1981. Introduction to quantitative genetics. Ed. 2. Longmans Green, London/New York.

Filipčev B., Simurina O., Bodroža-Solarov M., Obreht D. 2013. Comparison of the bread-making performance of spelt varieties grown under organic conditions in the environment of northern Serbia and their responses to dough strengthening improvers. Chemical Industry, OnLine-First (00):83-83.

Jablonskytė-Raščè D., Maikštėnienė S., Mankevičienė A. 2013. Evaluation of productivity and quality of common wheat (Triticum aestivum L.) and spelt (Triticum spelta L.) in relation to nutrition conditions. Zemdirbyste-Agriculture, 100: 45-56.

Kohajdová Z., Karovičová J. 2008. Nutritional value and baking applications of spelt wheat. Acta Scientiarium Polonorum, Technologia Alimentaria, 7: 5-14.

Konvalina P., Capouchová I., Stehno Z. 2013. Baking quality of hulled wheat species in organic farming. World Academy of Science, Engineering and Technology, 78: 105-108.

Lacko-Bartošová M., Korczyk-Szabó J. Ražný R. 2010. Triticum spelta - a specialty grain for ecological farming systems. Research Journal of Agricultural Science, 42: 143-147.

Lammerst van Bueren E.T., Hulscher M., Haring M., Jongerden J., Van Mansvelt J.D., Den Nijs A.P.M., Ruivenkamp G.T.P. 1999. Sustainable organic plant breeding. Eds. Lammerst van Bueren et al. Louis Bolk Institute, Driebergen, Netherlands, 160 . 
Marques C.D., Auria L., Cani P.D., Baccelli CH., Rozenberg R. 2007. Comparison of glycemic index of spelt and wheat bread in human volunteers. Food Chemistry, 100: 1265-1271.

Michigan State University 1990. User’s Guide to MSTAT-C.

Moudrý J., Konvalina P., Stehno Z., Capouchová I., Moudrý J.Jr. 2011. Ancient wheat species can extend biodiversity of cultivated crops. Scientific Research and Essays, 6: 4273-4280.

Muñoz-Insa A., Selciano H., Zarnkow M., Becker T., Gastl M. 2013. Malting process optimization of spelt (Triticum spelta L.) for the brewing process. LWT - Food Science and Technology, 50: 99-109.

Neeson R. 2011. Organic spelt production. Industry and Investment. Online available on: www.industry.nsw.gov.au/publications.

Piergiovanni A.R., Rizzi R., Pannacciulli E., Della Gatta C. 1997. Mineral composition in hulled wheat grains: a comparison between emmer (Triticum dicoccon Schrank) and spelt ( $T$. spelta L.) accessions. International Journal of Food Sciences and Nutrition 48: 381-386.

Pospisil A., Pospisil M., Svecnjak Z., Matotan S. 2011. Influence of crop management upon the agronomic traits of spelt (Triticum spelta L.). Plant Soil Environment, 57: 435-440.

Ruibal-Mendieta N.L., Dekezser A., Delacroix D.L., Mignolet E., Larondelle Y., Meurens M. 2004. The oleate / palmitate ratio allows the distinction between wholemeals of spelt (Triticum spelta L.) and winter wheat (T. aestivum L.). Journal of Cereal Science, 39: 413-415.

Siemianiowska E., Skibniewska K.A., Warechowska M., Jędrzejsczak M.F., Tybirski J. 2011. Flour and bread quality of spring spelt. World Academy of Science, Engineering and Technology, 59: 170-175.

Zečević V., Bošković J., Dimitrijević M., Petrović S. 2010. Genetic and phenotypic variability of yield components in wheat (Triticum aestivum L.). Bulg. J. Agric. Sci., 16: 422-428.

Zečević V., Bošković J., Knežević D., Milenković S., Mićanović D. 2013. Study of some spike characteristics in wheat (Triticum aestivum L.). Review on Agriculture and Rural Development, 2: 478-484.

Zhao F.J., Su Y.H., Dunham S.J., Rakszegi M., Bedo Z., McGrath S.P., Shewry P.R. 2009. Variation in mineral micronutrient concentrations in grain of wheat lines of diverse origin. Journal of Cereal Science, 49: 290-295. 